\title{
POSITIVE SOLUTIONS FOR A SINGULAR THIRD ORDER BOUNDARY VALUE PROBLEM
}

\section{Johnny Henderson, Rodica Luca, Charles Nelms JR. And Aijun Yang}

Abstract. The existence of positive solutions is shown for the third order boundary value problem, $u^{\prime \prime \prime}=f(x, u), 0<x<1, u(0)=u(1)=u^{\prime \prime}(1)=0$, where $f(x, y)$ is singular at $x=0$, $x=1, y=0$, and may be singular at $y=\infty$. The method involves application of a fixed point theorem for operators that are decreasing with respect to a cone.

Mathematics subject classification (2010): 34B16, 34B18.

Keywords and phrases: fixed point theorem; boundary value problem, singular.

\section{REFERENCES}

[1] R. P. AgARWAL AND D. O'REgan, Singular problems on the infinite interval modelling phenomena in draining flows, IMA J. Appl. Math. 66 (2001), 621-635.

[2] R. P. Agarwal, D. O’Regan and P. J. Y. Wong, Positive Solutions of Differential, Difference and Integral Equations, Dordrecht, The Netherlands, 1999.

[3] C. BAndle, R. SPerb AND I. STAKGOLD, Diffusion and reaction with monotone kinetics, Nonlinear Anal. 18 (1984), 321-333.

[4] J. V. BAXLEY, A singular boundary value problem: membrane response of a spherical cap, SIAM J. Appl. Math. 48 (1988), 855-869.

[5] F. Bernis And L. A. Peletier, Two problems from draining flows involving third order ordinary differential equations, SIAM J. Appl. Math. 27 (1996), 515-527.

[6] L. E. Bobisud, D. O'REgAn AND W. D. RoyALTy, Existence and nonexistence for a singular boundary value problem, Appl. Anal. 28 (1988), 245-256.

[7] L. E. Bobisud, D. O'REgAn AND W. D. RoyALTy, Solvability of some nonlinear singular boundary value problems, Nonlinear Anal. 12 (1988), 855-869.

[8] A. CAllegari And A. NAChman, Some singular nonlinear differential equations arising in boundary layer theory, J. Math. Anal. Appl. 64 (1978), 96-105.

[9] A. CAllegari AND A. NAChMAN, A nonlinear singular boundary value problem in the theory of pseudoplastic fluids, SIAM J. Appl. Math. 38 (1980), 275-281.

[10] P. W. Eloe AND J. Henderson, Singular nonlinear boundary value problems for higher order ordinary differential equations, Nonlinear Anal. 17 (1991), 1-10.

[11] J. A. Gatica, V. Oliker And P. Waltman, Singular nonlinear boundary value problems for second-order ordinary differential equations, J. Differential Equations 79 (1989), 62-78.

[12] J. R. GRAEF AND B. YANG, Existence and nonexistence of positive solutions of a nonlinear third order boundary value problem, Electron. J. Qual. Theory Differ. Equ. 9 (2008), 1-13.

[13] J. R. GRAEF AND B. YANG, Upper and lower estimates of the positive solutions of a higher order boundary value problem, J. Appl. Math. Comput. 41 (2013), 321-337.

[14] A. Granas, R. B. Guenther And J. W. Lee, A note on the Thomas-Fermi equation, Z. Angew. Math. Mech. 61 (1981), 204-205.

[15] K. S. HA AND Y. H. LEE, Existence of multiple positive solutions of singular boundary value problems, Nonlinear Anal. 28 (1997), 1429-1438.

[16] J. HENDERSON AND W. Yin, Singular $(k, n-k)$ boundary value problems between conjugate and right focal, J. Comput. Appl. Math. 88 (1998), no. 1, 57-69. 
[17] J. Hernandez, F. Mancebo and J. M. Vega, Positive solutions for nonlinear elliptic equations, Proc. Roy. Soc. Edinburgh 137A (2007), 41-62.

[18] C. D. LUNING AND W. L. PERRY, Positive solutions of negative exponent generalized Emden-Fowler boundary value problems, SIAM J. Math. Anal. 12 (1981), 874-879.

[19] M. MARoun, Positive solutions to a third-order right focal boundary value problem, Comm. Appl. Nonlinear Anal. 12 (2005), 71-82.

[20] M. Maroun, Positive solutions to an $n$th order right focal boundary value problem, Electron. J. Qual. Theory Differ. Equ. (2007), No. 4, 17 pp.

[21] D. O'REgAN, Positive solutions to singular and nonsingular second-order boundary value problems, J. Math. Anal. Appl. 142 (1989), 40-52.

[22] D. O'REGAN, Some new results for second order boundary value problems, J. Math. Anal. Appl. 148 (1990), 548-570.

[23] D. O'REGAN, Existence of positive solutions to some singular and nonsingular second order boundary value problems, J. Differential Equations 84 (1990), 228-251.

[24] P. SingH, A second-order singular three-point boundary value problem, Appl. Math. Lett. 17 (2004), 969-976.

[25] W. B. QU, Z. X. Zhang AND J. D. WU, Positive solutions to a singular second order three-point boundary value problem, (English summary) Appl. Math. Mech. (English Ed.) 23 (2002), 854-866.

[26] Z. WEI, Positive solutions of singular sublinear second order boundary value problems, Systems Sci. Math. Sci. 11 (1998), 82-88.

[27] X. YANG, Positive solutions for nonlinear singular boundary value problems, Appl. Math. Comput. 130 (2002), 225-234. 